\title{
Penerapan Model Pembelajaran Kooperatif Tipe Numbered Head Together (NHT) untuk Meningkatkan Aktivitas dan Hasil Belajar Rias Wajah Khusus dan Kreatif (Cikatri)
}

\author{
A. A. Oka Santi Suardini*
}

Smk Negeri 2 Singaraja, Indonesia

\begin{tabular}{l} 
A R T I C L E I N F O \\
\hline Article history: \\
Received 19 November \\
2018 \\
Received in revised form \\
30 December 2018 \\
Accepted 10 January 2019 \\
Available online 20 \\
February 2019 \\
Kata Kunci: \\
NHT, aktivitas, hasil \\
belajar, Rias Wajah \\
Khusus dan Kreatif \\
(Cikatri). \\
Keywords: \\
NHT, activities, learning \\
outcomes, Special and \\
Creative Makeup \\
(Cikatri).
\end{tabular}

\begin{abstract}
A B S T R A K
Penelitian ini bertujuan untuk meningkatkan aktivitas dan hasil belajar Rias Wajah Khusus dan Kreatif (Cikatri) melalui penerapan model pembelajaran kooperatif tipe NHT pada siswa kelas XI Tata Kecantikan 1 SMK Negeri 2 Singaraja tahun pelajaran 2017/2018. Penelitian ini tergolong penelitian tindakan kelas yang dilaksanakan dalam dua siklus, dengan bentuk guru sebagai peneliti. Subyek penelitian ini adalah siswa kelas XI Tata Kecantikan 1 yang berjumlah 36 orang. Data dianalisis menggunakan analisis statistik deskriptif. Hasil analisis data observasi awal aktivitas belajar Rias Wajah Khusus dan Kreatif (Cikatri) secara klasikal sebesar 33,33 (cukup aktif), setelah diberi tindakan pada siklus I meningkat menjadi 61,11 (aktif) dan meningkat menjadi 100 (aktif) pada siklus II. Analisis data ketuntasan hasil belajar pada observasi awal sebesar $27,78 \%$, setelah diberi tindakan pada siklus I meningkat menjadi $38,89 \%$ dan meningkat menjadi $100 \%$ pada siklus II. Berdasarkan hasil analisis data dan pembahasan, simpulan penelitian ini adalah aktivitas dan hasil belajar Rias Wajah Khusus dan Kreatif (Cikatri) meningkat melalui Implementasi Model Pembelajaran Kooperatif tipe NHT pada siswa kelas XI Tata Kecantikan 1 SMK Negeri 2 Singaraja tahun pelajaran 2017/2018. Disarankan kepada guru Tata Kecantikan dapat mengimplementasikan model pembelajaran kooperatif tipe NHTdalam proses pembelajaran karena dapat meningkatkan aktivitas dan hasil belajar Rias Wajah Khusus dan Kreatif (Cikatri).
\end{abstract}

A B S T R A C T

This study aims to improve the activities and learning outcomes of Special and Creative Facial Makeup (Cikatri) through the application of the NHT type cooperative learning model to students of class XI Tata Beauty 1 of SMK Negeri 2 Singaraja in the school year 2017 / 2018. This study is classified as classroom action research conducted in two cycles, with the form of a teacher as a researcher. The subjects of this study were 36th grade students of Tata Beauty 1 totaling 36 people. Data were analyzed using descriptive statistical analysis. The results of the analysis of the initial observation data of learning activities Special and Creative Facial Makeup (Cikatri) in a classical amounted to 33.33 (quite active), after being given the action in the first cycle increased to 61.11 (active) and increased to 100 (active) in the second cycle. The data analysis of completeness of learning outcomes at the initial observation was $27.78 \%$, after being given the action in the first cycle it increased to $38.89 \%$ and increased to $100 \%$ in the second cycle. Based on the results of data analysis and discussion, the conclusions of this study are the activities and learning outcomes of Special and Creative Facial Makeup (Cikatri) increased through the Implementation of NHT Cooperative Learning Model in class XI Tata Beauty 1 of SMK Negeri 2 Singaraja in the academic year 2017/2018. It is suggested that Tata Beauty teachers can implement the NHT type of cooperative learning model in the learning process because it can improve the activities and learning outcomes of Special and Creative Makeup (Cikatri). 


\section{Pendahuluan}

Proses Pembelajaran merupakan inti dari proses pendidikan secara keseluruhan dengan guru sebagai pemegang peranan utama. Di dalamnya terkandung serangkaian perbuatan guru dan siswa atas dasar hubungan timbal balik yang berlangsung dalam situasi edukatif untuk mencapai tujuan tertentu. Guru sebagai pendidik ataupun sebagai pengajar merupakan faktor penentu keberhasilan pendidikan di sekolan. Tugas guru yang utama adalah memberikan pengetahuan Cognitif,sikap/nilai affective, dan keterampilan psychomotor terhadap anak didik (Modul PLPG 2012 UNJ).

Sebagai pemegang peranan utama guru dituntut untuk mampu mengelola proses belajar mengajar baik dalam kompetensi pedagogi,kompetensikepribadian, kompetensi sosial dan kompetensi profesional(UU RI No.14 Tahun 2005 tentang Guru dan Dosen) . Termasuk di dalamnya penguasaan dalam penggunaan media pembelajaran yang memiliki fungsi untuk mengarahkan proses pembelajaran. Kemampuan guru untuk dapat menyesuaikan media pembelajaran dengan mata pembelajaran yang akan diberikan pada siswa dapat mempengaruhi keaktifan siswa dalam proses pembelajaran dimana media sebagai perantara untuk menjelaskan apa yang dapat diucapkan guru secara keseluruhan dengan adanya keterbatasan waktu mengajar ( Guswari,2011).

Upaya itu tidak lain untuk meningkatkan kualitas pendidikan. Seperti yang kita ketahui saat ini masalah pendidikan di Indonesia menjadi suatu masalah yang rumit dimana kebutuhan masyarakat akan pendidikan sangat tinggi seiring dengan perkembangan IPTEK dan pengaruh globalisasi, akan tetapi sebagian besar masyarakat masih dalam keadaan ekonomi yang sulit. Sehingga diperlukan suatu solusi untuk memecahkan masalah tersebut. Keberhasilan proses belajar mengajar ditentukan oleh beberapa factor antara lain siswa, guru, metode, sarana dan prasarana serta situasi kelas pada saat itu. Semua faktor diatas sangat berperan penting. Guru diharapkan dapat mengembangkan model pembelajaran sehingga siswa lebih memahami pelajaran Rias wajah khusus dan kreatif ( Cikatri) yang akan diajarkan. Guru dituntut menggunakan metode mengajar yang lebih baik, inovatif untuk memotivasi siswa dalam belajar. Pemilihan metode pengajaran dan model pembelajaran merupakan kompetensi dasar yang harus dimiliki oleh seorang guru.Selain itu agar dapat melaksanakan tugasnya dengan baik, profesional dan bertanggunga jawab, guru harus memiliki kepribadian yang mantap, stabil dan dewasa (Mulyasa, 2007:35).Namun dalam kenyataannya terdapat kesenjangan antara tujuan yang ingin dicapai dengan paradigma yang dipergunakan. Siswa di sekolah dijejali dengan informasi-informasi yang harus dikuasai, sementara kehidupan di masa depan menuntut pemecahan masalah baru secara inovatif. Paradigma belajar yang dewasa ini adalah belajar yang beroriantasi pada proyek, masalah, penyelidikan (inkuiri), penemuan dan penciptaan.

Berdasarkan hasil observasi pada saat pembelajaran berlangsung, ketika guru mengajar yang telah berlangsung di SMK N 2 Singaraja, ternyata pembelajaran Rias Wajah Khusus dan kreatif ( Cikatri) kelas XI TK 1 SMK N 2 Singaraja pada semester ganjil mengalami kendala-kendala dalam proses pembelajaran. Adapun Kendala-kendala tersebut, yaitu sebagai berikut: Pertama, hasil belajar siswa dalam pelajaran Rias Wajah Khusus dan kreatitif (Cikatri ) masih kurang maksimal. Keaktifan siswa dalam kelas dalam proses pembelajaran sangat rendah. Siswa yang aktif bertanya, menjawab, serta memberi komentar hanya sekitar 2 atau 3 orang dalam setiap pertemuannya. Belum maksimalnya hasil belajar siswa ini karena pembelajaran di dominasi dengan metode ceramah yang berpusat pada guru.

Pembelajaran yang diterapkan masih didasarkan pada teori tabularasa, yaitu pengetahuan dapat dipindahkan dari pikiran guru secara utuh ke pikiran siswa. Akibatnya, siswa akan mengalami kesulitan dalam mencerna pelajaran, siswa memiliki banyak pengetahuan tetapi tidak dilatih untuk menemukan pengetahuan dan konsep, sehingga siswa cenderung lebih cepat bosan dalam mengikuti pelajaran yang berdampak pada rendahnya hasil belajar. Sistem evaluasi yang diterapkan guru lebih ditekankan pengukuran kongnitif saja melalui pekerjaan rumah, ujian tengah semester dan ujian akhir semester. Guru jarang memperhatikan keaktifan siswa sehari-hari ketika mereka belajar seperti ketekunan dalam belajar, penampilan saat berdiskusi dan mengerjakan tugas yang diberikan dalam kelompok. Keempat, siswa sering kali meremehkan mata pelajaran Rias Wajah Khusus dan Kreatif ( Cikatri ) karena siswa sering menganggap bahwa mata pelajaran Rias Wajah Khusus dan Kreatif ( Cikatri) adalah mata pelajaran yang sangat mudah. Dari segi pelaksanaan proses pembelajaran ada unsur pendukung yang tidak dapat terlepaskan. Unsur tersebut adalah model pembelajaran. Model pembelajaran adalah salah satu dari bagian pendukung yang dapat menciptakan keberhasilan dari tujuan pembelajaran yang ingin dicapai. Model pembelajaran sangat diperlukan untuk memandu proses pembelajaran secara efektif.

Adapun permasalahan yang dialami siswa dalam pembelajaran Rias Wajah Khusus dan Kreatif (Cikatri) dari segi aktivitas belajar yaitu: (1) dilihat dari segi visual, pada saat diberikan contoh atau penjelasanada siswa yang tidak serius memperhatikan guru, memperhatikan teman dalam berdemonstrasi atau melakukan unjuk kerja mengenai materi Rias Wajah Khusus dan Kreatif (Cikatri), (2) 
dari segi lisan, siswa belum seluruh siswa berani mengemukakan pendapat dalam proses pembelajaran, (3) dari segi audio, siswa masih kurang mendengarkan guru dengan seksama dan ada siswa yang bercanda, (4) dari segi metrik, siswa belum mampu melakukan praktek rias wajah sesuai dengan materi pembelajaran Rias Wajah Khusus dan Kreatif (Cikatri) dengan baik dan benar, (5) dari segi mental, siswa belum bisa memecahkan kesulitan-kesulitan yang ditemui sendiri dan dialami langsung dalam proses pembelajaran, dan (6) dari segi emosional, siswa kurang bersemangat dan kurang berani dalam menghadapi dan memecahkan masalah dalam pembelajaran Rias Wajah Khusus dan Kreatif (Cikatri).

Dengan melihat kondisi yang seperti itu, maka dicarikan alternatif pemecahan masalah demi mencapai tujuan pembelajaran Tata Kecantikan yaitu membentuk manusia yang seutuhnya dilihat dari ketiga ranah pengetahuan, perilaku dan keterampilan.Salah satu alternatif pemecahan masalah yang peneliti tawarkan untuk memperbaiki aktivitas dan hasil belajar siswa tersebut, yaitu dengan menggunakan model pembelajaran kooperatif (cooperative learning) tipe Numbered Head Together(NHT). Model Pembelajaran tipe NHT adalah "jenis pembelajaran kooperatif yang dirancang untuk mempengeruhi pola interaksi siswa dan sebagai alternatif terhadap struktur tradisional" (Trianto, 2007:62).

Pemilihan penggunaan model pembelajaran kooperatif tipe NHT ini juga dikuatkan oleh hasil penelitian dari peneliti-peneliti sebelumnya yang berhasil, (1) Disimpulkan bahwa "aktivitas dan hasil belajar lompat jauh gaya jongkok dan gaya menggantung meningkat melalui model pembelajaran kooperatif tipe NHT pada siswa kelas XI IA 1 SMA Negeri 1 Kuta tahun pelajaran 2012/2013" (Suprana, 2013:112). (2) Disimpulkan bahwa "aktivitas dan hasil belajar teknik dasar passing sepak bola meningkat melalui model pembelajaran kooperatif Tipe Numbered Head Together (NHT) Pada Siswa Kelas X SMK Negeri 3 Singaraja tahun pelajaran 2014/2015"(Aryananda, 2011:104). (3)Disimpulkan bahwa "NHT adalah alat belajar yang lebih efektif bagi siswa yang berkinerja lemah dan anak laki-laki di Kimia dan terbukti efektif untuk mayoritas siswa lain, dibandingkan dengan belajar kimia secara individual" (Baker, 2013:31).(4) Disimpulkan bahwa "aktivitas dan hasil belajar tolak peluru meningkat melalui model pembelajaran kooperatif tipe NHT pada siswa kelas VII SMP Negeri 1 Sawan tahun pelajaran 2012/2013" (Ari, 2012:111).

Berdasarkan uraian di atas maka penulis tertarik untuk melakukan penelitian dan memecahkan masalah tersebut dengan judul "penerapan model pembelajaran kooperatif tipe numbered head together (NHT) untuk meningkatkan aktivitas dan hasil belajar Rias Wajah Khusus dan Kreatif (Cikatri) pada siswa kelas XITK 2 SMK Negeri 2 Singaraja Tahun Pelajaran 2017/2018".

Dalam setiap penelitian pasti selalu ada tujuan yang ingin dicapai. Tujuan yang ingin dicapai dalam penelitian ini adalah: (1) Untuk meningkatkan aktivitas belajar Rias Wajah Khusus dan Kreatif (Cikatri) melalui penerapan model pembelajaran kooperatif tipe NHT pada siswa kelas XITK 1 SMK Negeri 2 Singaraja Tahun Pelajaran 2017/2018. (2) Untuk meningkatkan hasil belajar Rias Wajah Khusus dan Kreatif (Cikatri) melalui penerapan model pembelajaran kooperatif tipe NHT pada siswa kelas XITK 1 SMK Negeri 2 Singaraja Tahun Pelajaran 2017/2018.

\section{Metode}

Penelitian ini adalah penelitian tindakan kelas (PTK) karena bertujuan memperbaiki kualitas pembelajaran yang bermuara pada peningkatan kualitas kinerja guru dan peningkatan aktivitas serta hasil belajar siswa. "Menurut Arikunto, dkk (2002: 3), menyatakan bahwa, "PTK merupakan suatu pencermatan terhadap kegiatan belajar sebuah tindakan, yang sengaja dimunculkan dan terjadi dalam sebuah kelas secara bersama." Penelitian ini dilaksanakan 2 (dua) siklus, di mana masing- masing siklus terdiri dari 2 (dua) kali pertemuan. Pada pertemuan pertama diberikan pembelajaran secara penuh, terkait materi yang diberikan, sedangkan pada pertemuan kedua diberikan pengulangan untuk memantapkan penguasaan materi yang sebelumnya telah diberikan pada pertemuan pertama, dan sekaligus pengambilan data hasil belajar Rias wajah khusus dan kratif (cikatri) dengan dievaluator oleh 1 orang yaitu: 1 orang guru Tata Kecantikan di SMK Negeri 2 Singaraja. Pada siklus I materi yang diberikan adalah pembelajaran Rias Wajah Khusus dan Kreatif (Cikatri), sedangkan pada siklus II materi yang diberikan materi pemantapan dari pembelajaran Rias Wajah Khusus dan Kreatif (Cikatri) jika terjadi ketidak tuntasan di siklus I.

Karena keterbatasan waktu, biaya, dan pengetahuan, maka penelitian ini dibatasi 2 siklus,.Siklus terdiri dari empat tahapan, yaitu: (1) Rencana tindakan, (2) Pelaksanaan tindakan, (3) observasi/evaluasi, dan (4) refleksi 


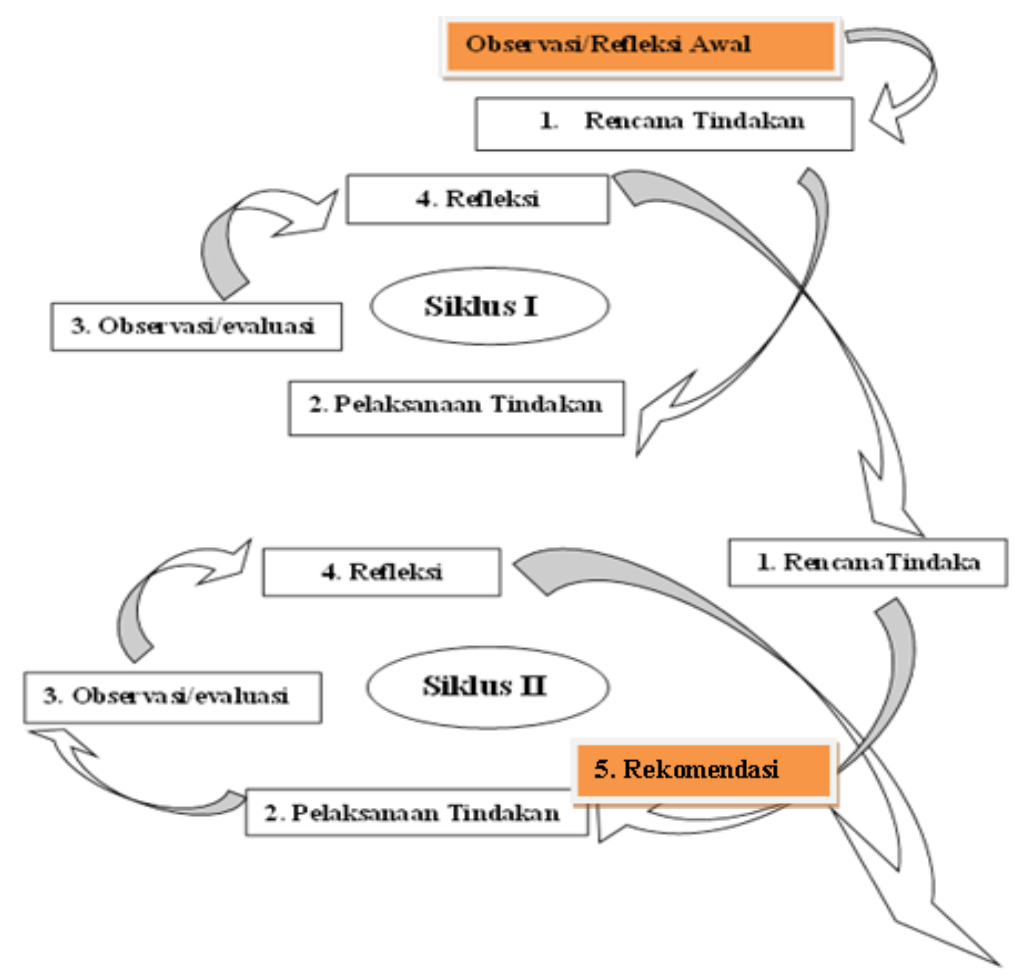

Gambar 1. Siklus PTK

\section{Siklus 1}

a. Rencana Tindakan

Perencanaan proses pembelajaran dilaksanakan pada tanggal 2 Oktober 2018 dilihat dari hasil observasi awal maka peneliti menerapkan pembelajaran dengan model pembelajaran kooperatif tipe NHT. Agar tindakan tersebut berjalan dengan baik dan sesuai dengan tujuan yang telah dirumuskan hal yang perlu dipersiapkan meliputi: (1) membuat rencana pembelajaran sesuai dengan topik bahasan Rias Wajah Khusus dan Kreatif (Cikatri), (2) menyiapkan model pembelajaran yaitu menerapkan langkahlangkah pembelajaran kooperatif tipe NHT, (3) membentuk kelompok, dari 36 orang siswa dibagi menjadi 6 kelompok, dimana setiap kelompok beranggotakan 6 orang, (4) mengklarifikasikan materi pembelajaran menjadi bagian-bagian yang sederhana, (5) menyiapkan asessmentuntuk mengetahui tingkat aktivitas belajar siswa dan format assesmen untuk mengetahui tingkat hasil belajarRias Wajah Khusus dan Kreatif (Cikatri), (6) menyiapkan sarana dan prasarana yang diperlukan dalam proses pembelajaran Rias Wajah Khusus dan Kreatif (Cikatri).

b. Pelaksanaan Tindakan

Pelaksanaan tindakan proses pembelajaran siklus I dilaksanakan sesuai dengan jadwal pembelajaran, tindakan yang dilakukan dibagi dalam dua pertemuan. Pembelajaran ditekankan pada permasalahan yang ditemukan pada saat observasi awal. Dalam proses pembelajaran, model yang digunakan dalam memecahkan suatu masalah dari hasil observasi adalah dengan menggunakan model pembelajaran kooperatif tipe NHT. Waktu setiap pertemuan adalah 360 menit.

c. Observasi dan Evaluasi Siklus I

Observasi/evaluasi pada siklus I dilakukan pada tanggal 18 September 2018 hal ini dilakukan untuk mengetahui aktivitas dan hasil Rias Wajah Khusus dan Kreatif (Cikatri) akibat dari tindakan yang dilaksanakan pada siklus I.

d. Refleksi Siklus I

Setelah observasi/evaluasi dilakukan, peneliti mengkaji pelaksanaan tindakan dan mendiskusikan kekurangan-kekurangan pembelajaran pada siklus I yang dilaksanaka pada tanggal 2 Oktober 2018.Berdasarkan hasil analisis data aktivitas pada siklus I, bahwa rata-rata aktivitas belajar Rias Wajah Khusus dan Kreatif (Cikatri) secara klasikal adalah 80 dan dalam kategori aktif, walaupun sudah termasuk dalam kategori aktif tetapi masih ada beberapa siswa yang masih belum aktif dalam pembelajaran Rias Wajah Khusus dan Kreatif (Cikatri) 


\section{Siklus II}

Seperti halnya siklus pertama, siklus kedua pun terdiri dari perencanaan, pelaksanaan, pengamatan/observasi dan refleksi. Penelitian ini telah dilaksanakan pada siswa kelas XITK 1 SMK Negeri 2 Singaraja yang berjumlah 36 orang putra 0 orang dan 36 putri tahun pelajaran 2017/2018 dalam pembelajaran Rias Wajah Khusus dan Kreatif (Cikatri) pada pukul 07.15 wita sampai 13.45. wita yang dilaksanakan pada hari selasa dan jumat bertempat di ruang Rias mulai yang dilaksanakan pada tanggal 2 Oktober 2018, 5 Oktober 2018, 16 Oktober 2018 dan 19 Oktober 2018.

Subyek penelitian adalah siswa, guru, pegawai, atau kepala sekolah.Dalam konteks pembelajaran disekolah, subyek penelitian umumnya adalah siswa. Penelitian ini melibatkan partisipasi siswa kelas XITK 1 SMK Negeri 2 Singaraja yang berjumlah 36 orang terdiri dari putra 0 orang dan putri 36 orang.

Teknik pengambilan data aktivitas belajar Rias Wajah Khusus dan Kreatif (Cikatri)dilakukan pada tiap siklus. Tiap siklus terdiri dari 2 kali pertemuan pembelajaran, maka akan diambil data aktivitas Rias Wajah Khusus dan Kreatif (Cikatri) maksimal sebanyak 4 kali. Sementara pengumpulan data hasil belajar siswa dibagi menjadi tiga yaitu dari aspek pengetahuan, aspek sikap, dan aspek keterampilan. Dalam penelitian ini, teknik analisis data yang digunakan adalah analisis statistik deskriptif.

\section{Hasil dan Pembahasan}

Dapat dijelaskan pada pelaksanaan siklus I, katagori sangat aktif sebanyak 6 siswa $(16,677 \%)$, aktif sebanyak 16 siswa (44,44\%), cukup aktif sebanyak 14 siswa (38,89\%), kurang aktif 0 siswa $(0,0 \%)$, dan sangat kurang aktif 0 siswa $(0,0 \%)$. Dengan memperhatikan data aktivitas belajar pada siklus I dalam hal ini aktivitas belajar rias wajah cikatri.Dari hasil analisis aktivitas belajar rias wajah cikatri, adapun permasalahannya yaitu siswa belum mengamati guru dalam mendemonstrasikan rias wajah cikatri, siswa belum berani mengemukakan pendapat dan memberikan saran dalam diskusi, siswa belum melakukan percobaan praktek rias wajah untuk membantu menyempurnakan riasan yang dilakukan, dan siswa belum percaya diri dalam menghadapi dan memecahkan masalah.Tindakan-tindakan yang dilakukan untuk mengatasi permasalahan tersebut adalah menekankan pemahaman model pembelajaran kooperatif, memotivasi siswa kembali agar lebih bersemangat dan aktif mengikuti pembelajaran, dan memperbanyak kelompok dan memperkecil anggota kelompok. Sehingga pada akhirnya memperoleh hasil aktivitas belajar rias wajah cikatri secara klasikal pada Siklus I adalah 81berada dalam kategori aktif.

Data hasil belajar siklus I pada kompetensi pengetahuan, sikap, dan keterampilan adalah siswa yang berada pada kategori sangat baik sebanyak 2 siswa (5,56\%), baik sebanyak 29 siswa $(80,56 \%)$, cukup sebanyak 5 siswa $(13,89 \%)$, dan kurang tidak ada $0(0 \%)$ maka diketahui hasil belajar rias wajah cikatri secara klasikal pada Siklus I adalah 81 dan berada pada kriteria baik atau persentase tuntas.

Dengan tercapainya hasil belajar siswa tersebut maka penelitian ini akan dilanjutkan ke siklus II dengan melihat kekurangan dan permasalahan pada siklus I. Permasalahan yang ditemukan adalah: siswa belum mengamati guru dalam mendemonstrasikan rias wajah cikatri, siswa belum berani mengemukakan pendapat serta memberikan saran dalam diskusi, siswa belum melakukan percobaan praktek untuk membatu menyempurnakan riasan wajah dan siswa belum percaya diri dalam menghadapi serta memecahkan masalah.

Aktivitas belajar siswa pada siklus II yaitu siswa yang berada pada katagori sangat aktif sebanyak 13 siswa (36,11\%), aktif sebanyak 23 siswa (63,89\%), cukup aktif tidak ada (0\%), kurang aktif tidak ada $(0 \%)$, dan sangat kurang aktif tidak ada $0(0 \%)$ dan secara keseluruhan siswa yang tuntas sebanyak 100 $\%$. Maka diketahui aktivitas belajar rias wajah cikatri secara klasikal pada Siklus II adalah 87 berada pada kriteria aktif atau persentase tuntas. Hasil belajar pada siklus II siswa yang berada pada kategori sangat baik sebanyak 5 siswa $(13,89 \%)$, baik sebanyak 31 siswa $(86,11 \%)$, cukup tidak ada $(0,0 \%)$, dan kurang tidak ada (0 \%). Maka diketahui hasil belajar rias wajah cikatri secara klasikal pada Siklus II adalah 86 dan berada pada kriteria baik atau persentase tuntas.

Berdasarkan hasil analisis data dari penerapan model pembelajaran kooperatif tipe NHT yang bertujuan untuk meningkatkan aktivitas dan hasil belajar rias wajah cikatri, hasil penelitian aktivitas belajar siswa pada siklus I terhadap pembelajaran tata kecantikan khususnya pada materi rias wajah cikatri secara klasikal berada pada kategori aktif. Sedangkan rata-rata hasil belajar rias wajah cikatri berada pada kategori baik.Dengan memperhatikan aktivitas dan hasil belajar rias wajah cikatri pada siklus I peneliti akan melanjutkan ke siklus II dengan melihat permasalahan-permasalahan pada siklus I. Hal ini terbukti dari refleksi dari siklus I yang masih terdapat permasalahan-permasalahan dalam pelaksanaan tindakan. Adapun permasalahan-permasalahan yang dihadapi dalam pembelajaran pada siklus I yaitu: (1) kurangnya pemahaman siswa terhadap model pembelajaran kooperatif tipe NHT, (2) Siswa kurang fokus dalam mendengarkan penjelasan dari peneliti tentang rias wajah cikatri, (3) Siswa kurang memperhatikan demonstrasi yang diperagakan oleh peneliti dan teman dalam melakukan 
demonstrasi, sehingga siswa kesulitan dalam mengingat rias wajah cikatri, (4) Siswa takut mengajukan pertanyaan dan mengemukakan pendapat terkait kesulitan yang dialami selama proses pembelajaran, (5) siswa kurang bersemangat dan besungguh-sungguh dalam melakukan rias wajah cikatri, (6) pandangan siswa pada saat melakukan praktek rias wajah cikatrimasih kurang, (7) kurangnya kesempatan siswa dalam melakukan praktek rias wajah cikatri sehingga hasilnya kurang maksimal.

Berdasarkan permasalahan-permasalahan yang dihadapi pada siklus I tersebut maka adapun solusinya yaitu: (1) mensosialisasikan kembali terkait model pembelajaran kooperatif tipe NHT pada siswa, (2) siswa diintruksikan agar disiplin dan mendengarkan penjelasan dari peneliti sehingga materi yang disampaikan peneliti dapat diserap dengan baik, (3) mengintruksikan kepada siswa agar berkonsentrasi dan bersungguh-sungguh pada saat melakukan praktek rias wajah cikatri sehingga pandangan dapat mengarah ke depan, (4) mengintruksikan siswa agar lebih berani dalam mengajukan pertanyaan dan mengemukakan pandapat pada siklus II tentang rias wajah cikatri, sehingga permasalahan dalam pembelajaran dapat dipecahkan bersama-sama, (5) memberikan motivasi agar siswa menjadi lebih bersemangat dan bersungguh-sungguh dalam mengikuti pembelajaran pada siklus II tentang rias wajah cikatri, (6) menyuruh siswa agar lebih berkonsentrasi dan lebih memperhatikan demonstrasi yang diperagakan oleh peneliti maupun kelompok pada siklus II tentang rias wajah cikatri, (7) membagi siswa menjadi jumlah kelompok yang lebih banyak sehingga jumlah siswa dalam satu kelompok lebih sedikit sehingga kesempatan dalam melakukan praktek di setiap siswa menjadi lebih banyak, selain itu peneliti juga memberikan modul bacaan kepada setiap kelompok sehingga dapat lebih memberikan pemahaman ke siswa terkait dengan materi pembelajaran.

Pembelajaran pada siklus II berlangsung sangat kondusif, siswa sudah mengetahui dan mampu beradaptasi dengan model pembelajaran kooperatif tipe NHT.Hal ini terlihat dari aspek aktivitas belajar siswa, saat peneliti memperagakan praaktek tidak lagi hanya menonton tetapi aktif bertanya terhadap penjelasan peneliti disetiap tahap praktek yang diperagakan oleh peneliti.Rata-rata aktivitas belajar rias wajah cikatri secara klasikal tergolong sangat aktif.Sedangkan untuk penguasaan materi rias wajah cikatri berada dalam kategori sangat baik.Peningkatan ini tidak terlepas dari penerapan model pembelajaran kooperatif tipe NHT secara optimal dengan perbaikan-perbaikan pembelajaran sesuai dengan kekurangan-kekurangan yang terjadi pada siklus atau pembelajaran sebelumnya.

Penelitian ini dikuatkan oleh penelitian sebelumnya yang dilakukan oleh Rika Fima Yenni (2016) menyatakan Berdasarkan hasil perhitungan menggunakan software minitab diperoleh P-value $=0,016$ pada taraf kepercayaan $95 \%(\alpha=0,05)$. Karena P-value $<\alpha$ maka tolak H0 dan terima H1. Ini berarti hasil belajar matematika siswa yang menggunakan metode NHT lebih baik dari pada hasil belajar matematika siswa yang menggunakan pembelajaran konvensional. Nursyamsi SY (2016) menyatakan dari perbandingan rerata terkoreksi diketahui bahwa strategi pembelajaran NHT memberikan pengaruh lebih besar, yaitu sebesar $21,56 \%$, dibandingkan pengaruh yang disebabkan oleh pembelajaran konvensional. Mutia Agisni Mulyana (2016) Menyatakan bahwa Model kooperatif tipe Numbered Heads Together (NHT) dapat meningkatkan hasil belajar siswa pada materi kenampakan alam dan sosial budaya. Siti Nuryanti (2014) juga menyatakan penerapan model pembelajaran kooperatif tipe Numbered Head Together dapat meningkatkan hasil belajar IPA siswa Kelas IV SD Negeri 3 Tondo Palu.

Widodo (2013) menyatakan terkait hasil belajar bahwa dengan menggunakan metode pembelajaran berbasis masalah dapat meningkatkan kegiatan pembelajaran dan hasil belajar siswa. Monawati (2016) juga menyatakan bahwa upaya meningkatkan Hasil Belajar Siswa melalui Lesson Study pada Penjumlahan Pecahan di Kelas IV SDN Lamsayeun. Pukjiwati (2017) menyatakan penelitian pendekatan CTL ini dapat meningkatkan kualitas hasil belajar siswa terhadap mata pelajaran Matematika tentang Operasi Hitung Pecahan dalam Pemecahan Masalah kelas IV SD Negeri Sumur 03, Kecamatan Cluwak, Kabupaten Pati, melalui media belajar dan mengajar.

Berdasarkan hasil pada penelitian yang sudah dilaksanakan, secara umum penelitian ini sudah dapat membantu siswa untuk meningkatkan aktivitasnya dalam proses pembelajaran sehingga hasil belajar yang diperoleh lebih baik dan maksimal. Namun peneliti juga mengalami keterbatasan yaitu, hanya memilih model pembelajaran kooperatif tipe NHT untuk meningkatkan aktivitas dan hasil belajar rias wajah cikatri.Sehingga hasil ini belum sempurna karena dari hasil yang diperoleh masih terdapat siswa yang tergolong belum memenuhi standar ketuntasan belajar yang diterapkan.

\section{Simpulan Dan Saran}

Berdasarkan hasil analisis data dan pembahasan di atas dapat ditarik simpulan sebagai berikut. (1) Aktivitas belajar rias wajah khusus dan kreatif (cikatri) meningkat melalui penerapan model pembelajaran kooperatif tipe Numbered Head Together (NHT) pada siswa kelas XI TK1 SMK Negeri 2 Singaraja tahun pelajaran $2017 / 2018$. Hal ini dapa tdilihat dari data peningkatan yang terjadi pada 
aktivitas belajar rias wajah khusus dan kreatif (cikatri)secara keseluruhan. (2) Hasil belajar rias wajah khusus dan kreatif (cikatri)meningkat melalui penerapan model pembelajaran kooperatif tipe Numbered Head Together (NHT) pada siswa kelas XI TK1 SMK Negeri 2 Singaraja tahun pelajaran 2017/2018. Hal ini dapa tdilihat dari data peningkatan yang terjadi pada hasil belajar rias wajah khusus dan kreatif (cikatri) secara keseluruhan.Berdasarkan uraian tersebut, maka dapat disimpulkan bahwa aktivitas dan hasil belajar rias wajah khusus dan kreatif (cikatri) meningkat melalui penerapan model pembelajaran kooperatif tipe Numbered Head Together (NHT) pada siswa kelas XI TK1 SMK Negeri 2 Singaraja tahun pelajaran 2017/2018.

Dari hasil penelitian tersebut dapat disarankan. (1) Kepada guru tata kecantikan kulit dan rambut dapat menerapkan model pembelajaran kooperatif tipe Numbered Head Together (NHT) pada pembelajaran rias wajah khusus dan kreatif (cikatri) karena dapat meningkatkan aktivitas dan hasil belajar siswa. (2) Bagi peneliti lain yang akan mengadakan penelitian dapat menerapkan model pembelajaran kooperatif tipe Numbered Head Together (NHT) sesuai dengan materi yang akan diberikan. (3) Bagi sekolah agar dijadikan pedoman dalam pembelajaran Rias wajah khusus dan kreatif pada materi rias wajah cikatri . (4) Bagi siswa-siswi yang dijadikan subjek penelitian selanjutnya lebih memperhatikan dan memahami pembelajaran yang diberikan, agar dapat menambah paradigma maupun wawasan pengetahuan khususunya dalam pembelajaran rias wajah khusus dan kreatif (cikatri) maupun pada pembelajaran yang lain.

\section{Daftar Rujukan}

Arikunto, S. 2002. Prosedur Penelitian. Jakarta: Rineka Cipta

Astrawan, I Gede Budi.2012."Penerapan Model Kooperatif Tipe NHT Dalam Meningkatkan Hasil Belajar Siswa Pada Mata Pelajaran IPA Di Kelas V SD N 3 Tonggolobibi. Jurnal Kreatif Tadulako Online Vol. 3 No. 4ISSN 2354-614X

Monawati, M. Yamin. 2016. Upaya Meningkatkan Hasil Belajar Siswa Melalui Lesson Study Pada Penjumlahan Pecahan Di Kelas IV Sdn Lamsayeun. JURNAL PESONA DASAR Universitas Syiah Kuala. Vol. 3 No.4, Oktober.

Mutia Agisni Mulyana, Nurdinah Hanifah, Asep Kurnia Jayadinata. 2016. Penerapan Model Kooperatif Tipe Numbered Heads Together (NHT) Untuk Meningkatkan Hasil Belajar Siswa Pada Materi Kenampakan Alam Dan Sosial Budaya. Jurnal Pena Ilmiah UPI. Vol 1 No 1.

Nursyamsi SY, Aloysius Duran Corebima, Herawati Susilo. 2016. Pengaruh Strategi Pembelajaran Numbered Heads Together (NHT) terhadap Hasil Belajar Siswa SMA Negeri 1 Muara Badak. Jurnal Pendidikan: Teori, Penelitian, dan Pengembangan. Vol 1 No 10 Edisi Oktober.

Pukjiwati. 2017. Upaya Meningkatkan Aktivitas Hasil Belajar Siswa Pada Materi Pecahan Dengan Pendekatan Contextual Teaching and Learning Kelas IV SDN Sumur 03. JURNAL REFLEKSI EDUKATIKA Universitas Muria Kudus. Volume 7 (2).

Rasyid Dan Mansur. (2008). Penilaian Hasil Belajar.Bandung: CV Wacana PrimaJurnal Kreatif Tadulako Online Vol. 3 No. 4ISSN 2354-614X242

Rika Fima Yenni. 2016. Penggunaan Metode Numbered Head Together (NHT) Dalam Pembelajaran Matematika. Jurnal Penelitian dan Pembelajaran Matematika. Jurnal Penelitian dan Pembelajaran Matematika. Vol 9 No 2.

Siti Nuryanti. 2014. Penerapan Model Pembelajaran Kooperatif Tipe Numbered Head Together (Nht) Untuk Meningkatkan Hasil Belajar Siswa Pada Mata Pelajaran Ipa Kelas IV Sd Negeri 3 Tondo. Jurnal Diknas. Volume 2 No 2.

Slameto. (2003). Belajar Dan Faktor-Faktor Yang Mempengaruhinya. Jakarta: Rineka Cipta.

Suryanto. (2009). Evaluasi Pembelajaran Di SD. Jakarta: Universitas Terbuka.

Syuaib, Dahlia. (2012). Penelitian Tindakan Kelas. Palu: Edukasi Mitra Grafika 
Trianto. 2007. Model-Model Pembelajaran Inovatif Berorientasi Konstruktivistik. Jakarta: Prestasi Pustaka.

Widodo, Lusi Widayanti. 2013. Peningkatan Aktivitas Belajar Dan Hasil Belajar Siswa Dengan Metode Problem Based Learning Pada Siswa Kelas Viia Mts Negeri Donomulyo Kulon Progo. Jurnal Fisika Indonesia No: 49, Vol XVII, Edisi April. 